\title{
The potential of transgenic chickpeas for pest control and possible effects on non-target arthropods
}

\author{
Jörg Romeis ${ }^{\mathrm{a}, *}$, Hari C. Sharma ${ }^{\mathrm{b}}$, Kiran K. Sharma ${ }^{\mathrm{b}}$, Sampa Das ${ }^{\mathrm{c}}$, Bidyut K. Sarmah ${ }^{\mathrm{d}}$ \\ ${ }^{a}$ Swiss Federal Research Station for Agroecology and Agriculture, Reckenholzstr. 191, Zurich 8046, Switzerland \\ ${ }^{\mathrm{b}}$ International Crops Research Institute for the Semi-Arid Tropics (ICRISAT), Patancheru, Andhra Pradesh 502 324, India \\ ${ }^{\mathrm{c}}$ Bose Institute, P1/12 C.I.Z. Scheme VII(M), Kolkata 700 054, India \\ ${ }^{\mathrm{d}}$ Department of Agricultural Biotechnology, Assam Agricultural University (AAU), Jorhat, Assam 7985 013, India
}

Received 13 November 2003; received in revised form 4 February 2004; accepted 10 February 2004

\begin{abstract}
Chickpea, Cicer arietinum, is the third most important grain legume crop in the world, with India being the largest producer. Insect pests are a major constraint to chickpea production. In India, the legume pod borer Helicoverpa armigera is the major insect pest of chickpeas. However, sap-sucking insects that act as vectors for viral diseases and bruchid beetles in storage are also considered important pests. Here we give an overview over the different management options to control these pests. There is a growing interest in the genetic modification of crops to enhance their resistance against insect pests. Here we present the state-of-theart of chickpea transformation and give an overview on the available insecticidal genes that could be deployed to increase insect resistance in chickpea. Prior to commercialization, transgenic crops have to be assessed for their effects on the environment including the possible impact on non-target arthropods, many of which are important for biological pest control. Therefore, the arthropod-food web in the Indian chickpea system is described. Possible routes through which entomophagous insects could be exposed to insecticidal proteins expressed by genetically modified chickpeas are discussed, and species that could be selected for prerelease risk assessment are recommended.
\end{abstract}

(C) 2004 Elsevier Ltd. All rights reserved.

Keywords: Aphis craccivora; Callosobruchus spp.; Cicer arietinum; Genetic engineering; Helicoverpa armigera; Insect resistance; Pest management; Risk assessment

\section{Introduction}

Chickpea (Cicer arietinum L.) is the third most important grain legume crop in the world after dry beans and peas (FAO, 2003). While this pulse crop is an important source of dietary protein for human consumption, it is also important for the management of soil fertility due to its nitrogen-fixing ability (Maiti, 2001). The chickpea probably originated in an area of south-eastern Turkey and adjoining Syria, but is now cultivated throughout the semi-arid regions of the world (Jodha and Subba Rao, 1987). Chickpea has enormous prospects especially under marginal land and water resource situations. Chickpeas are often divided into two major groups (Muehlbauer and Singh, 1987). The

\footnotetext{
*Corresponding author. Tel.: +41-1-377-7299; fax: +41-1-3777201.

E-mail address: joerg.romeis@fal.admin.ch (J. Romeis).
}

'desi' types produce small, angular seeds that are variously pigmented and are grown principally on the Indian subcontinent and in East Africa. The 'kabuli' types have relatively large, round seeds of white or pale cream colour and are predominantly grown in the Mediterranean region and in Central and South America.

In 2002, the worldwide chickpea area harvested was 10.7 million hectares and total grain production was 8.2 million tonnes. India is the largest producer and consumer of chickpea in the world, and accounts for more than $60 \%$ of the area harvested and of the total worldwide production (FAO, 2003). Over the past 40 years, considerable progress has been made in chickpea production. While the grain yield in farmer's fields in India has increased from about $0.55 \mathrm{tha}^{-1}$ in the early $1960 \mathrm{~s}$ to an average of $0.8 \mathrm{tha}^{-1}$, productivity has stayed stable between 4 to 6 million tonnes which is primarily due to a decrease in the area harvested (FAO, 2003). 
Despite this progress, there is still a large gap in grain yields between the average productivity on farmer's fields and the maximum yield potential of up to $6 \mathrm{tha}^{-1}$ recorded in field trials conducted in the Mediterranean region (Singh, 1987). While low inputs and sub-optimal crop management accounts significantly for this gap, diseases and insect pests are also major constraints to chickpea production. The enhancement of insect and disease resistance in chickpea can increase its yield potential by as much as three times (ICRISAT, 1992). However, due to the lack of sources of resistance to these constraints in the available germplasm, the success rates of genetic enhancement of the chickpea by conventional plant breeding has been modest. Possibilities for further breakthroughs will therefore largely depend on alternate sources of resistance from wild species or through the use of modern tools in biotechnology.

Genetic transformation to enhance crop resistance or tolerance to biotic constraints is regarded as having good potential to achieve more sustainable food production in less-developed areas of the world such as the semi-arid tropics where agrochemicals are frequently inaccessible to farmers (Sharma and Ortiz, 2000; Sharma et al., 2001). Considering the potential impact that biotechnology can have on the livelihoods of resource-poor farmers, India is investing an increasing amount of resources into plant biotechnology (Paarlberg, 2001; Raghuram, 2002; Sharma et al., 2003a). The interest in genetically modified (GM) plants is likely to grow after the commercial release of transgenic cotton in 2002 that expresses the insecticidal cryl Ac gene of the soil bacterium Bacillus thuringiensis (Bt) (James, 2002), and the apparent success in controlling the pod borer Helicoverpa armigera (Hübner) (Lepidoptera: Noctuidae) (Quaim and Zilberman, 2003). However, prior to deployment, each crop and transgene combination needs a close examination for its potential to benefit the poor (Atkinson et al., 2001) and possible environmental effects (Dale et al., 2002; Conner et al., 2003). Here we provide an overview of the most important insect pests of chickpea in India and their management as well as the potential to control these pests using GM chickpeas. We further present information on the beneficial arthropods that are active in the chickpea crop and suggest species that could be tested as part of a regulatory risk assessment.

\section{Insect pests of chickpea and their management}

Even though a number of insect herbivores have been reported to be associated with chickpea (Van Emden et al., 1988; CPC, 2001), only three groups, i.e. the legume pod borer $H$. armigera, sap-sucking pests [especially Aphis craccivora Koch (Hemiptera: Aphididae)] and bruchid beetles belonging to the genus Callosobruchus [C. chinensis Linnaeus, C. maculates Fabricius, $C$. analis Fabricius] cause major economic losses in India (Reed et al., 1987). One reason for the paucity of herbivores on chickpea is the dense layer of nonglandular and glandular trichomes, which cover the surface of all green plant parts, and the highly acidic exudate excreted by the glandular trichomes (Cubero, 1987).

\subsection{Helicoverpa armigera}

The legume pod borer is one of the most serious and widespread pests in the Old World. Its serious pest status has mainly been attributed to the high fecundity, extensive polyphagy, strong dispersal ability, and a facultative diapause. The larval preference for feeding on plant parts rich in nitrogen such as reproductive structures and growing tips results in extensive crop losses (Fitt, 1989). In chickpea, H. armigera is the dominant field pest and yield losses of up to $40 \%$ have been reported from farmer's fields in India (Reed et al., 1987; Srivastava and Srivastava, 1990). Worldwide losses due to $H$. armigera in chickpea have been estimated at over US\$ 330 million annually (ICRISAT, 1992).

While a $1977-82$ survey revealed that less than $10 \%$ of farmers used pesticide to control $H$. armigera in chickpea (Reed et al., 1987), the shift from subsistence to commercial production and the resulting substantial rise in the price of the crop has provided farmers with the opportunity to consider pest management options which formerly would have been uneconomic, leading to an increased use of pesticides (Shanower et al., 1998). A wide variety of insecticides have been used to control $H$. armigera, and in many areas, several applications are needed to contain this pest (Reed et al., 1987; Sachan, 1992). Intensive insecticide application to control $H$. armigera on various crops (especially cotton) has resulted in the development of resistance to the major classes of insecticides such as chlorinated hydrocarbons, organophosphates, synthetic pyrethroids and carbamates (Armes et al., 1996). This has resulted in control failures and a lack of confidence in chemical control among the farming communities (Raynolds and Armes, 1994).

Since 1976, more than 14,000 chickpea germplasm accessions and breeding lines have been screened for resistance to $H$. armigera at the International Crops Research Institute for the Semi-Arid Tropics (ICRISAT) under open-field, pesticide-free conditions. Several genotypes with low to moderate levels of resistance were identified (Lateef and Sachan, 1990). However, while the resistant lines suffered less pod damage, they often produced lower yields than the controls, which was partly due to the relatively small seed size of some of the 
resistant lines (Shanower et al., 1998). In addition, most of the resistant/tolerant lines were found to be susceptible to diseases, particularly to Fusarium wilt and Ascochyta blight (Lateef and Sachan, 1990). So far, few varieties with enhanced levels of resistance to $H$. armigera have been released for cultivation by the farmers (Sharma et al., 2003b). In recent years, much has been learned about the mechanisms of $H$. armigera resistance in chickpea. Ovipositional antixenosis is one of the components of resistance (Lateef, 1985; Cowgill and Lateef, 1996). In addition, inhibition of larval growth by malic acid and oxalic acid contained in the trichome exudates (antibiosis) appears to be an important mechanism (Cowgill and Lateef, 1996; Yoshida et al., 1995). Other antibiosis factors include Helicoverpa gut protease inhibitor activity in developing chickpea seeds (Patankar et al., 1999) and phenyl ammonialyase activity in leaves (Bhatnagar et al., 2000).

While a number of parasitoids and predators have been reported to attack $H$. armigera in India, their presence and impact in chickpea is generally low (Romeis and Shanower, 1996). The most efficient species is the parasitic wasp Campoletis chlorideae Uchida (Hymenoptera: Ichneumonidae), for which parasitism levels of up to $30 \%$ of young larvae have been reported (Romeis and Shanower, 1996). The low activity of natural enemies in chickpea is most probably due to the dense trichome layer on the plant surface and the acid exudates (Jalali et al., 1988; Murray and Rynne, 1994; Romeis et al., 1999).

The use of microbial pathogens including Helicoverpa nucleopolyhedrovirus (HaNPV), entomophatogenic fungi, nematodes and biopesticides such as $B t$-products and neem seed kernel extract have shown some potential to control H. armigera (Saxena and Ahmed, 1997; Shanower et al., 1998; Lingappa and Hegde, 2001). In particular, HaNPV has been demonstrated to be a viable option to control H. armigera in chickpea as it can be as effective as the chemical pesticides (Rabindra et al., 1992; Cowgill and Bhagwat, 1996; Cherry et al., 2000). However, there are still two major obstacles for widespread adoption of this technology. The first is the high production costs that make the viral treatments uncompetitive compared with the synthetic insecticides, and the second is the lack of an effective product quality control system (Jenkins and Grzywacz, 2000; Cherry et al., 2000).

Cultural control options such as manipulation of plant spacing, time of sowing, intercropping and soil operations such as ploughing have also been shown to have some potential to reduce the damage caused by H. armigera (Reed et al., 1987; Shanower et al., 1998).

\subsection{Sap-sucking pests}

Sap-sucking pests infesting chickpeas reach pest status mainly due to the fact that they act as virus vectors. Aphids, especially $A$. craccivora, are known to transmit a large number of viral diseases in chickpea (Kaiser et al., 1990). The most important is a strain of the bean leaf roll luteovirus, the main cause of chickpea stunt, which is transmitted in a persistent manner by A. craccivora (Brunt et al., 1996). Another chickpea disease is caused by the chickpea chlorotic dwarf virus (Horn et al., 1995), a tentative mastrevirus (Fauquet and Stanley, 2003). This virus is transmitted in a persistent, non-propagative and circulative manner by the leafhopper Orosius orientalis (Matsumura) (Hemiptera: Cicadellidae) (Horn et al., 1994; Brunt et al., 1996).

Aphids are generally not controlled in the chickpea crop. While pesticides have been reported to be effective against $A$. craccivora (Sharma et al., 1991), their application is expected to be of limited value since the aphids would still transmit the virus before dying, therefore preventing only secondary virus spread (Reed et al., 1987). In addition, $A$. craccivora has already developed some levels of resistance to a number of common insecticides (Dhingra, 1994). Little is known on possible mechanisms of resistance in chickpea to aphid attack. Weigand and Tahhan (1990) have reported that a lower $\mathrm{pH}$ in leaf washings correlates with a smaller number of aphids found on the plant.

\subsection{Bruchids}

Damage in chickpea storage in India caused by Callosobruchus spp. varies among geographical regions with reported average infestation levels of up to $13 \%$ (Mookherjee et al., 1970; Dias and Yadav, 1988).

Even though chemical pesticides have the potential to give good protection against bruchid attack (Rahman and Yadav, 1987; Yadav and Singh, 1994; Lal and Dikshit, 2001), their adoption in chickpea storage appears to be small (Srinivasu and Naik, 2002). Extensive screening of seeds of kabuli type chickpeas against bruchids have not revealed any acceptable level of resistance (Weigand and Pimbert, 1993). In contrast, desi type seeds with enhanced levels of resistance have been reported (Raina, 1971; Schalk et al., 1973; Weigand and Tahhan, 1990). Unfortunately, resistant lines usually produce relatively small seeds with a rough seed coat which is unacceptable to consumers (Reed et al., 1987). One way of reducing the oviposition by bruchid beetles is to store split chickpea seeds as used for dal preparation (Reed et al., 1987). Biological control of bruchids has not really been exploited in India, despite the use of different plant products (Boeke et al., 2001). A comprehensive review of biological control of bruchids in the tropics has been published by Van Huis (1991). 


\section{Potential of transgenic insect-resistant chickpeas}

\subsection{Genetic transformation of chickpea: current status}

Non-sexual DNA transfer techniques make possible the manipulations that are outside the repertoire of breeding and cell fusion techniques (Sharma and Ortiz, 2000). Genes can be accessed from exotic sources (plant, animal, bacterial, viral) and introduced in the crop of interest. However, the lack of availability of efficient transformation methods to introduce foreign genes can be a substantial barrier to the application of recombinant DNA methods in some crops including legumes such as chickpea. A reliable shoot regeneration protocol is a prerequisite for efficient application of genetic transformation strategies. Several regeneration protocols involving somatic embryogenesis (Rao and Chopra, 1989; Barna and Wakhlu, 1993; Sagare et al., 1993; Dineshkumar et al., 1994; Suhasini et al., 1994) and shoot organogenesis (Shri and Davis, 1992; Barna and Wakhlu, 1994) in chickpea have been reported from diverse explants in both mature and immature tissues with varying success rates (Sonia et al., 2004). However, the recovery frequency of regenerated plants and their transfer to the glasshouse has been very low, which has limited the progress in genetic transformation of chickpea. More recently, an efficient and reproducible protocol for the regeneration of shoots at high frequency has been developed at ICRISAT that uses explants derived from the axillary meristems of cotyledonary nodes of in vitro-germinated seedlings of chickpea (Jayanand et al., 2003). This includes effective rooting of the in vitro formed shoots and their successful transplantation to the glasshouse with high frequencies.

Chickpea has been shown to be susceptible to wild Agrobacterium tumefaciens as well as A. rhizogenes, where infection results in the formation of crown galls and hairy roots, respectively, on the infected explant (Sonia et al., 2004). Even though the genetic transformation of chickpea has been reported where the primary transformants were confirmed by molecular analysis (Fontana et al., 1993; Kar et al., 1996, 1997; Krishnamurthy et al., 2000), the methods were genotype dependent and produced low frequencies of transgenic tissue or plantlets.

Krishnamurthy et al. (2000) used embryo axes devoid of root and shoot meristems for A. tumefaciensmediated transformation of chickpea. The binary vectors contained two marker genes, the uidA gene expressing $\beta$-glucuronidase and the antibiotic selection marker $n p t$ II. After co-cultivation with Agrobacterium and selection on the antibiotic kanamycin, 16 shoots were obtained from nearly 4000 explants resulting in a transformation efficiency of $0.4 \%$. Due to problems with efficient rooting, the shoots were grafted onto germinated seedlings of wild type chickpea prior to their hardening and transfer to soil. Genomic analysis was carried out for only 4 out of the 16 plants, which revealed the integration of single or multiple copies of T-DNA. The plantlets transferred to soil had reduced vigour and fertility, which the authors attributed to the suboptimal glasshouse conditions. Out of 36 plants growing in glasshouse, only 5 plants flowered and set seeds. $\mathrm{T}_{1}$ progeny as analyzed by polymerase chain reaction (PCR) was found to be positive for the selection marker (nptII) but not for histochemical GUS assay measuring the $\beta$-glucuronidase activity.

A robust and reliable protocol for A. tumefaciensmediated chickpea transformation has recently been demonstrated by Sarmah et al. (2004) using cotyledonary explants containing half embryogenic axes. The Australian 'desi-type' cultivar Semsen was transformed by using a bean gene construct that encodes for an $\alpha$ amylase inhibitor and $n p t I I$ as the selectable marker gene. Average transformation frequency was $0.72 \%$ and therefore higher than reported in previous studies (Krishnamurthy et al., 2000). However, since the transgenes were transmitted to the next generation by only $78 \%$ of the primary transgenics, transformation efficacy based on the functionally transformed explants was $0.56 \%$. Southern blot analyses revealed that five out of six independent transgenic lines contained a single transgene insertion what is in contrast to earlier studies where multiple gene inserts were more frequently observed (Kar et al., 1996; Krishnamurthy et al., 2000).

At ICRISAT, chickpea transgenic lines have been developed by incorporating a synthetic Bt crylAb and soybean trypsin inhibitor gene through $A$. tumefaciensmediated genetic transformation by using the regeneration protocol based on axillary meristem explants that produce adventitious shoots (Jayanand et al., 2003; K.K. Sharma, unpublished results). The molecularly characterised plants are currently in $\mathrm{T}_{3}$ generation and being employed in insect bioassays for resistance to $H$. armigera. The protocol is applicable across a wide range of desi-type chickpea cultivars.

An overall view of the scenario of transformation in chickpea clearly demonstrates that considerable progress has been made in regeneration and genetic transformation of chickpea that had earlier remained a problematic crop for genetic engineering (Sonia et al., 2004). With this progress it is hoped that chickpea biotechnology will provide unique opportunities for its agronomic improvement against insect pests and other constraints to its productivity.

\subsection{Candidate genes for genetic transformation of chickpea for insect resistance}

\subsubsection{Helicoverpa armigera}

While a number of different types of insect-resistant genes are reported to encode for toxins that target 
lepidopteran larvae and could thus be suitable to increase resistance of chickpea and other crops (Schuler et al., 1998; Hilder and Boulter, 1999), Bt-toxins still receive the most attention. $H$. armigera is sensitive to a range of $B t$-toxins, with CrylAc being the most effective (Chakrabarti et al., 1998a; Kranthi et al., 2001; Liao et al., 2002). Synergistic activity of Cry1Ac and Cry1F toxins was also observed (Chakrabarti et al., 1998b). A recent study reported a five-fold variation in the sensitivity to CrylAc in $H$. armigera populations collected in different geographical regions in India (Jalali et al., 2004). So far, the only Bt-transgenic crop that has been commercialised for the control of $H$. armigera is cotton (James, 2002; Quaim and Zilberman, 2003). However, several other crops have successfully been transformed to express different cry genes for protection against this pest. These include tobacco (Selvapandiyan et al., 1998), brinjal (Kumar et al., 1998), potato (Chakrabarti et al., 2000) and tomato (Mandaokar et al., 2000; Kumar and Kumar, 2004). Two chickpea cultivars (ICCV 1 and ICCV 6) have been transformed to express the crylAc gene under a constitutive promotor (CaMV35S) through microprojectile bombardment using the $n p t I I$ gene as the selection marker (Kar et al., 1997). Young shoots of T1 plants that expressed Cry1Ac at $0.004-0.0045 \%$ of soluble protein caused a feeding inhibitory effect on first-instar $H$. armigera. Unfortunately, the presence and expression of transgenes and resistance level in subsequent progenies have not been reported.

A number of studies have investigated the proteinase activity in the gut of $\mathrm{H}$. armigera and the possible use of protease inhibitors (PIs) to control this pest. H. armigera has the highly alkaline midgut characteristics of Lepidoptera and secretes serine proteases as the main gut endoproteinases (Johnston et al., 1991). This explains the effects of serine PIs such as the soybean Kunitz trypsin inhibitor (SBTI) on H. armigera larvae in artificial diet bioassays (Johnston et al., 1991, 1993; Nandeesha and Prasad, 2001; Gatehouse et al., 2002) or when expressed by transgenic tobacco plants (Wu et al., 1997; Charity et al., 1999; Christeller et al., 2002; but see Nandi et al., 1999). Recent studies by Patankar et al. (2001) have also revealed the presence of metallo-, aspartic-, and cysteine-proteinase inhibitors in the larval gut. The authors reported a considerable diversity in the proteinase activity and a flexibility in their expression during the various developmental stages of the insect and depending upon the diet provided. The latter was suggested to be linked to the polyphagous nature of $H$. armigera which had evolved mechanisms to cope with different PIs that are encountered on the different host plants (Harsulkar et al., 1999). Further evidence for this is the fact that inhibitors of trypsin activity from host plants such as chickpea and pigeonpea (Cajanus cajan) do not have a strong effect on $H$. armigera
(Godbole et al., 1994; Giri et al., 1998; Patankar et al., 1999). Such adaptations have also been reported for $H$. armigera feeding on artificial diets containing individual PIs (Bown et al., 1997; Gatehouse et al. 1997), or when feeding on transgenic tobacco plants expressing the giant taro proteinase inhibitor (Wu et al., 1997). Due to this adaptability, the use of PIs as a single resistance strategy must be considered carefully. One of the ways to use PIs may be to combine inhibitors that target different proteinases (Jongsma and Bolter 1997; Harsulkar et al., 1999), or preferably, to use PIs in alliance with other insecticidal gene products. For example, synergistic effects of soybean trypsin inhibitor and $B t$ toxins on $H$. armigera have been reported by Zhang et al. (2000). The suggested mechanism was an extended retention time of the $B t$-toxins in the insect's midgut.

Recently, transgenic tobacco plants expressing avidin, a protein that binds strongly to the vitamin biotin, have shown good protection against $H$. armigera (Burgess et al., 2002). Pyramiding the avidin gene with $\operatorname{cryl} \mathrm{Ba}$ has resulted in a strong synergistic effect, while avidin expressing plants were as effective as plants that expressed avidin and a serine PI (aprotinin, BPTI).

At Assam Agricultural University, chickpeas have been transformed to express $c r y l A c$ driven by either the constitutive CaMV35S promoter or a green tissue specific promoter (AraSSU). Presence and expression of the transgene are currently being confirmed by PCR and Western analyses (B.K. Sarmah, unpublished results). Research is currently in progress at ICRISAT to develop transgenic chickpeas expressing $B t$-toxins, protease inhibitors, and lectin genes for resistance to $H$. armigera (Sharma and Ortiz, 2000; Sharma et al., 2002). Transgenic plants pyramiding Bt-genes (crylAb or cryl $A c$ ) and the SBTI gene are at different stages of evaluation for resistance to $H$. armigera (K.K. Sharma and H.C. Sharma, unpublished results).

\subsubsection{Sap-sucking pests}

Until now, no transgenic plant expressing a resistance factor against sap-sucking pests has been commercialised. While there is a patent available on $B t$-toxins that affect aphids (Payne and Cannon, 1993), there is no published evidence for this. The focus of research has therefore been on other insecticidal compounds. Plantderived lectins appear to be the most promising candidates. Lectins are carbohydrate-binding proteins that are thought to play a defensive role in plants in response to attack by herbivores or pathogens (Peumans and van Damme 1995). So far, transgenic crops expressing lectins from snowdrop (Galanthus nivalis, GNA) (Shi et al., 1994; Down et al., 1996; Stoger et al., 1999; Foissac et al., 2000), jackbean (Canavalia ensiformis, ConA) (Gatehouse et al., 1996) or wheat (Triticum vulgaris, WGA) (Kanrar et al., 2002) have shown partial resistance to aphids (Aphididae), leafhoppers 
(Cicadellidae) and planthoppers (Delphacidae). Besides the lectins that have been expressed in transgenic plants, a number of other lectins have been found to affect sapsucking insects when provided in artificial diets (Habibi et al., 1993; Rahbé et al., 1995; Sauvion et al., 1996; Bandyopadhyay et al., 2001; Roy et al., 2002). Because many of the sap-suckers are phloem-feeders, studies are in progress to target the transgene products to the phloem-sap by the use of phloem-specific promoters such as the rice sucrose synthase promotor (RSs1) (Shi et al., 1994).

In aphids, lectins appear to act primarily by reducing growth, development, and fecundity rather than causing mortality. This makes the additional impact of antagonists such as predators and parasitoids necessary for pest control (Van Emden, 1999). In addition, some studies have suggested a 'feeding deterrent' effect of lectins (Shi et al., 1994; Powell et al., 1995; Kanrar et al., 2002), which appears to be a consequence of intoxification rather than sensory-mediated (Sauvion et al., 2004). Changes in the insect feeding behaviour could potentially increase virus spread due to an increase in the frequency of plant visits and probing by the vectors, which is especially likely for non-persistant viruses (Kennedy, 1976). Since both the bean leaf roll luteovirus and the chickpea chlorotic dwarf virus are transmitted by their vector in a persistent manner (Horn et al., 1994; Brunt et al., 1996), a feeding deterrent effect of lectinexpressing transgenic chickpeas might not cause an increase in virus spread (Kennedy, 1976). However, this would need further investigation once lectin-expressing chickpea plants are available since virus spread will depend on the amount of time an aphid spends feeding on the plant and the inoculation and retention times of the virus. For example, the minimum acquisition access period reported for $O$. orientalis was found to be only 2 mins (Horn et al., 1994). Also, chickpea stunt is caused by a number of different viruses (Horn, 1994), for which the mode of transmission is not yet known. If chickpea diseases cannot be controlled by enhancing resistance towards the vector, plants could be genetically engineered to target the virus directly (Schillberg et al., 2001; Dasgupta et al., 2003). However, this approach might not be durable since viruses evolve rapidly (Prins, 2003).

So far, only a few mannose-binding lectins have been tested for their activity against $A$. craccivora in artificial diet bioassays: leaf lectins from garlic (Allium sativum, ASAL), onion (Allium cepa) and Diffenbachia sequina as well as a lectin from tubers of Colocasia esculenta. Of the four lectins tested, ASAL was found to be the most effective against $A$. craccivora [with a median effective dose $\left(\mathrm{LC}_{50}\right)$ of $0.15 \mathrm{nmol}$, followed by that of onion, $C$. esculenta and D. sequina (Sampa Das, unpublished results). After incubating $A$. craccivora on an artificial diet containing a sublethal dose of ASAL, the aphid's midgut was dissected and challenged with anti-ASAL antibodies. Light microscopic observations demonstrated the binding of the lectin to the inner epithelial membrane of $A$. craccivora which may explain the insecticidal activity of ASAL. At least some of the mannose binding lectin ASAL appears to remains stable when passing through the gastrointestinal tract, at least to the extent that immunoreactive peptides are detectable. This is important since biochemical stability is a prerequisite for biological activity of the lectin. ASAL has earlier been shown to be effective against sap-sucking pests, i.e. the aphid Lipaphis erysimi Kaltenbach (Hemiptera: Aphididae) and the red cotton bug Dysdercus cingulatus (Fabricius) (Hemiptera: Pyrrhocoridae) (Bandyopadhyay et al., 2001, Roy et al., 2002). ASAL is therefore a potential agent to control A. craccivora and chickpea transformation work has commenced using the lectin coding sequence driven by either a constitutive (CaMV35S) or phloemspecific (RSs1) promoter (Sampa Das, unpublished results).

\subsubsection{Bruchids}

While a number of plant derived lectins have been shown to affect Callosobruchus species when provided in artificial seeds, those with specificity for $N$-acetylgalactosamine/galactose or $N$-acetylglucosamine seem to be the most effective in inhibiting larval development (Murdock et al., 1990; Gatehouse et al., 1991; Zhu et al., 1996; Huesing et al., 1991a,b; Machuka et al., 2000; Macedo et al., 2002b).

Bruchids use cysteine proteinases as their predominant digestive enzymes with an optimum activity at about pH 5 (Ryan, 1990), explaining the reported effects of protease inhibitors (PIs) of the cysteine group (Murdock et al., 1988; Campos et al., 1989; Kuroda et al., 1996; Oliveira et al., 2001a, 2002; Macedo et al., 2002a). In addition, activity of aspartic proteinases has been reported in C. maculatus larvae (Silva and XavierFilho, 1991). The reported effects of the cowpea trypsin inhibitor on growth and development of $C$. maculatus larvae (Gatehouse and Boulter, 1983) is due to the fact that this PI shows a low level inhibitory activity against cysteine type proteinases (Gatehouse et al., 1985). Recently, Zhu-Salzman et al. (2003) reported a synergistic delay in development of $C$. maculatus by a recombinant fusion protein consisting of the soybean cysteine protease inhibitor soyacystatin and Griffonia simplicifolia lectin II, whereas a mixture of the separate proteins only showed an additive effect.

A range of other compounds isolated from legume seeds have shown insecticidal activity to Callosobruchus spp. These include polysaccharides (Applebaum et al., 1970; Oliveira et al., 2001b), proteins with unknown functions such as canatoxin (Carlini et al., 1997) and zeatoxin (Macedo et al., 2000), and storage proteins such as vicilins (Macedo et al., 1993; Yunes et al., 1998). 
By far the most effective compounds are those lectinlike proteins that inhibit the insects $\alpha$-amylases, enzymes that catalyse the hydrolysis of $\alpha-1,4$-glucan linkages in starch components, glycogen and other carbohydrates. Such inhibitors ( $\alpha$-AIs) with activity against Callosobruchus spp. have been purified from different plant sources (Franco et al., 2002). The best characterised inhibitor, $\alpha$-AI-1, has been purified from the common bean Phaseolus vulgaris and the cDNA has been cloned (Moreno and Chrispeels, 1989; Chrispeels et al., 1998). $\alpha$-AI-1 is known to inhibit the amylases of three important Old World bruchid pests. Bioassays deploying artificial seeds revealed that the presence of $\alpha$-AI- 1 at a level of $0.2 \%(\mathrm{w} / \mathrm{w})$ almost completely inhibits the development of larvae of $C$. chinensis and C. maculatus (Ishimoto and Kitamura, 1989). In addition, transgenic peas expressing $\alpha$-AI-1 have shown good protection against Bruchus pisorum (L.) (Schroeder et al., 1995). For comparison, the $\alpha$-amylases of the Mexican bean weevil Zabrotes subfasciatus (Boheman) are not inhibited by $\alpha$-AI-1 (Ishimoto and Kitamura, 1989). While $\alpha$ AI-1 is inactive against plant and bacterial enzymes, it also inhibits mammalian $\alpha$-amylases (Chrispeels et al., 1998). Therefore this anti-nutritional factor must be inactivated by cooking prior to human consumption. Inhibitors that affect Callosobruchus spp. $\alpha$-amylases but not those of mammals have also been reported (Yamada et al., 2001; Franco et al., 2002). For example, some wild accessions of the common bean contain an inhibitor $(\alpha-\mathrm{AI}-2)$ that exclusively inhibits insect $\alpha$-amylases. While $\alpha$-AI-2 inhibits the $\alpha$-amylases of $Z$. subfasciatus, it is not effective against $C$. maculatus, and far less active against $C$. chinensis when compared to $\alpha$-AI-1 (Suzuki et al., 1993).

Peas (Pisum sativum L.) (Shade et al., 1994) and adzuki beans (Vigna angularis) (Ishimoto et al., 1996) were genetically modified to express the bean cDNA encoding $\alpha$-AI-1. A $\alpha$-AI-1 gene construct was used that is regulated by flanking sequences from the seed-specific bean phytohemagglutinin (PHA-L) gene (dlec2). The PHA-L regulatory DNA sequences restrict the expression of the $\alpha$-AI- 1 to the cotyledon and embryonic axis of the developing seeds (Schroeder et al., 1995). Transgenic peas were tested for their resistance to $C$. maculatus and C. chinensis in the laboratory (Shade et al., 1994). For C. chinensis, in nearly every seed where $\alpha$-AI1 was detected, all infesting larvae died. Seeds from which adults emerged contained a maximum of $0.14 \%$ (w/w) of the inhibitor. The response of C. maculatus was more variable and depended on the level of $\alpha$-AI- 1 in the seeds, with levels of above $0.8 \%$ giving complete mortality. Subsequent experiments showed that $\alpha$-AI cDNA was expressed stably in transgenic pea seeds at least to the $T_{5}$ generation (Schroeder et al., 1995). Transgenic peas in which the $\alpha$-AI-1 level reached approximately $3.5 \%$ of the total protein, provided complete protection against B. pisorum, both in greenhouse as well as in field studies (the pea weevil lays its eggs on developing green pods) (Schroeder et al., 1995; Morton et al., 2000). Larval development was found to be blocked at an early developmental stage (Schroeder et al., 1995). Studies with transformed adzuki beans that expressed $\alpha$-AI- 1 in their seeds at a level of $0.9 \%$ dry weight were found to be completely resistant to three species of Callosobruchus spp. but not, as expected, to $Z$. subfasciatus (Ishimoto et al., 1996). Peas expressing $\alpha$ AI-2 in their seeds were not protected from $B$. pisorum (Morton et al., 2000).

Transgenic chickpea lines that express $\alpha$-AI- 1 in their seeds were developed using an Australian cultivar. The $\alpha$-AI-1 produced in chickpeas was shown to be functionally active against $\alpha$-amylase from porcine pancreas in vitro. Transgenic chickpeas expressing $\alpha$ AI-1 at a level of $2.1 \%$ of seed protein inhibited the development of $C$. maculatus and $C$. chinensis by over $90 \%$ in insect bioassays (Sarmah et al., 2004). Thus the $\alpha$-AI-1 gene is considered as effective for developing transgenic chickpeas resistant to storage pests. Presently, a transformation system has been established for Indian chickpea cultivars (Das et al., 2002) and transgenics are being developed using a reconstructed bean $\alpha$-AI-1 gene (B.K. Sarmah, unpublished results).

\section{Possible effects of insect-resistant GM chickpeas on entomophagous arthropods}

Among the widely discussed environmental impacts of GM crops is their potential effect on non-target organisms including entomophagous insects (Dale et al., 2002; Conner et al., 2003). Since parasitoids and predators are important for natural pest regulation, they help to prevent secondary pest outbreaks and can affect the rate of resistance evolution of the target pest to the introduced resistance factor (Gould et al., 1991; Gould, 1994). A risk assessment should therefore be carried out for the economically or ecologically most important species associated with the crop prior to the commercial release of the novel plant. Such a regulatory testing and risk assessment is well established for pesticides (Candolfi et al., 2001) and there are many lessons to learn for risk assessment of GM plants (Hill and Sendashonga, 2003). Recently, Dutton et al. (2003) have proposed a tiered testing procedure for insectresistant GM plants with increasing levels of complexity and realism that has largely been adapted from the ecotoxicological evaluation of pesticides. As a first step, it is required to determine which entomophagous arthropods play an important role in regulating pests in the respective GM crop. Since risk is defined as a product of a hazard (toxicity of a transgene product) and exposure (level of exposure to the compound), it has 
to be established which of the selected arthropods are potentially exposed to the transgene product under field conditions in a second step. For the arthropods that are likely to be exposed, their sensitivity to the product then has to be established (hazard identification and characterisation). The potential hazard of the insecticidal proteins will vary with their spectrum of activity. While $B t$-toxins are known to be active on a subset of species belonging to the same insect order, other compounds such as lectins or protease inhibitors have a less-specific mode of action, potentially affecting many more nontarget species (Schuler et al., 1998; Hilder and Boulter, 1999). Based on the information gained, the potential risk of a certain GM plant on non-target organisms can be characterised and possibly managed (Hickson et al., 2000; Dutton et al., 2003).

The application of this approach to crop systems in tropical areas, where the arthropod communities are usually not well described, is a challenge. In the following, we discuss possible routes through which entomophagous insects could be exposed to insecticidal proteins expressed by GM chickpeas. We further recommend species that could be selected for a prerelease risk assessment taking the availability/amenability and the knowledge on the species' biology into account since these are important prerequisites for setting up reliable and reproducible bioassays.

Even though a number of insect herbivores have been reported to be associated with chickpea (Van Emden et al., 1988; CPC, 2001), we will confine our focus on the three major pests in India, i.e. H. armigera, aphids and bruchids (Fig. 1). This is done, firstly, because these are the only chickpea herbivores for which information regarding their antagonists is available, and, secondly, any disturbance of the natural control of the herbivores that are not targeted by a particular GM chickpea should be avoided. There are a number of routes through which entomophagous arthropods could be exposed to the transgene products. (i) Carnivory of herbivorous arthropods-The predominant route for entomophagous insects to be exposed to transgene products is through their prey or hosts. Therefore it has to be assessed at an early stage which herbivores ingest the transgene product when feeding on a GM chickpea. This will depend on the mode of feeding of the herbivores and on the site and time of toxin expression (Dutton et al., 2003). The latter will vary with the promoter that drives the transgene. Bt-chickpeas that are currently developed express the Cry1Ac toxin under a constitutive (CaMV35S) or green tissue specific (Ara $\mathrm{SSU})$ promoter, expression of $\alpha$-AI- 1 is restricted to the seeds while it is envisaged to express ASAL under a phloem-specific (RSs1) promoter. In addition, concentration of a transgene product within an insect can also vary among species with a similar mode of feeding (Foissac et al., 2000; Head et al., 2001). (ii) Direct plant feeding - $\mathrm{A}$ number of predators are facultative feeders on plant material (incl. pollen) (Coll and Guershon, 2002). While transgene products have so far not been detected in nectar of GM crops (Malone and PhamDelègue, 2001), pollen may contain the novel proteins when constitutive promoters such as CaMV35S are used (for Bt-maize see Dutton et al., 2003). (iii) Honeydew feeding-Transgene products have been detected in the sugar-rich excretions (honeydew) from phloem-sucking Sterrnorhyncha (Hemiptera) feeding on insect-resistant transgenic plants. This indicates that the transgene product was present in the phloem-sap and could potentially affect a broad range of non-target arthropods including entomophagous insects that use honeydew as an energy source (Romeis et al., 2003). The presence of transgene products in honeydew has been observed not only in cases where the trangenes were driven by a phloem-specific promoter such as RSs1 (Shi et al., 1994) but also in cases where a constitutive promoter was deployed (Kanrar et al., 2002; Bernal et al., 2002; Rahbé et al., 2003).

In addition, transgene products also enter the soil ecosystem either through crop residue or herbivore detritus and can be detectable in the soil for a long period of time resulting in exposure of non-target soil organisms to the compound. The effects of GM plants on soil communities and processes in soil have been reviewed recently by Bruinsma et al. (2003) and Kowalchuk et al. (2003).

The entomophagous arthropods that attack $H$. armigera in India are relatively well known (Fig. 1). However, information regarding their impact and activity in the chickpea crop is still scarce (Romeis and Shanower, 1996). From the parasitoids reported to attack H. armigera on chickpea, Campoletis chlorideae is particularly abundant and effective (Romeis and Shanower, 1996). This along with the fact that $C$. chlorideae can be reared in the laboratory and is relatively well studied (e.g. Nikam and Gaikwad, 1991; Murugan et al., 2000) makes it a possible candidate for risk assessment studies. Only a few predatory arthropods are reported from chickpea (Mehto et al., 1986; Singh et al., 1990) (Fig. 1). One of the species, the ladybird beetle Coccinella septempunctata L. (Coleoptera: Coccinellidae), is a well established test insect for ecotoxicological studies (Schmuck et al., 2000). This species is known to attack both lepidopteran larvae as well as aphids (including A. craccivora on chickpea; Saxena et al., 1970), making it a good test species. Several other aphid predators have been reported in India, although not from chickpea (Waterhouse, 1998; Joshi et al., 1997). There is no published information on the parasitoids that attack aphids on chickpea, and field investigations should be conducted to describe the parasitoid complex involved. In the meantime, one might have to consider species that attack the chickpea infesting aphids on 


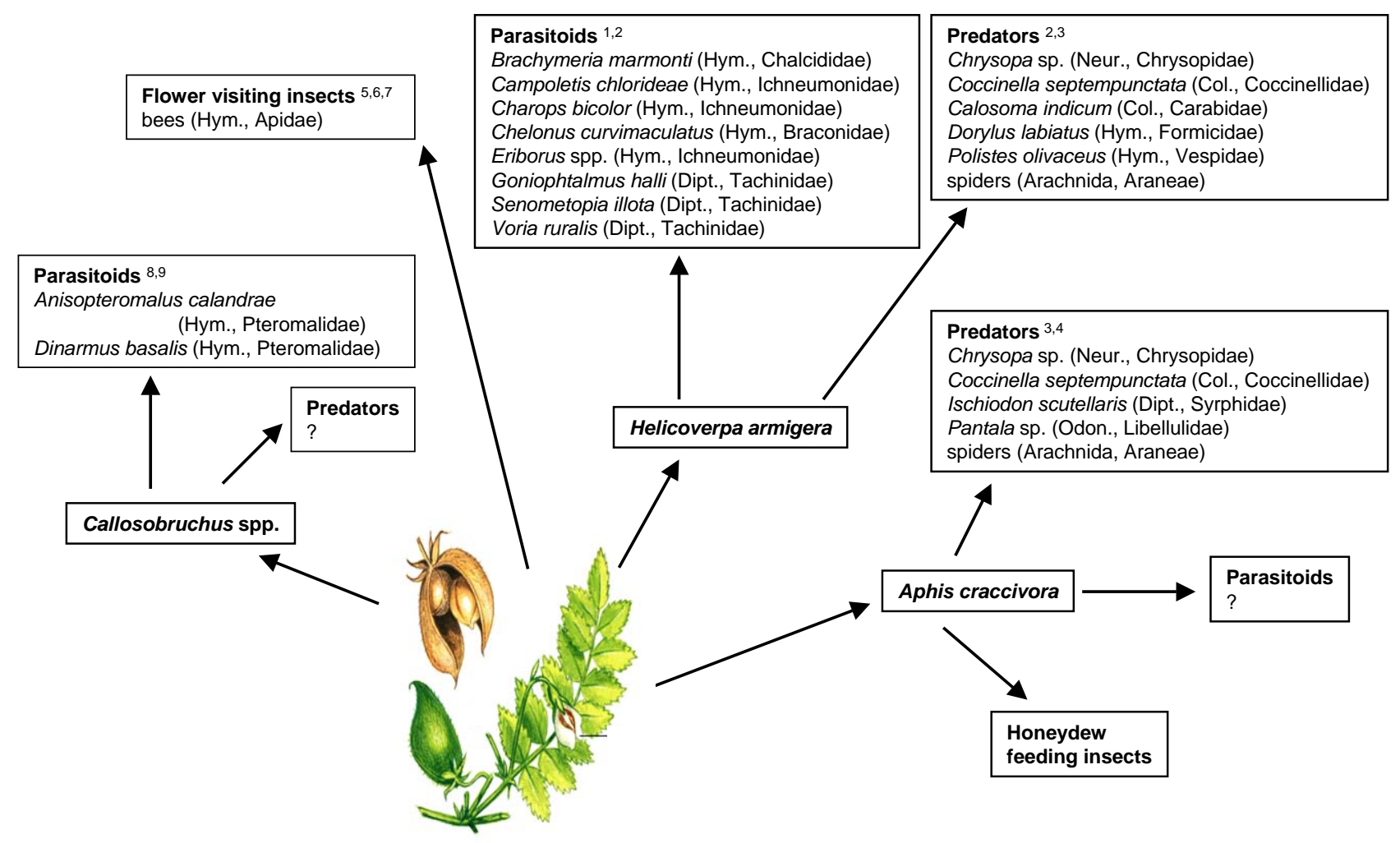

Fig. 1. Trophic interactions in the chickpea crop in India (1-Romeis and Shanower, 1996; 2-Singh et al., 1990; 3-Mehto et al., 1986; 4 -Saxena et al., 1970; 5-Ayyar, 1935; 6-Niknejad and Khosh-Khui, 1972; 7-Reed et al., 1987; 8-Devi, 1996; 9-Verma, 1991).

other crops for risk assessment studies. Parasitoids reported to attack $A$. craccivora in India have been listed by Waterhouse (1998). Indigenous parasitoids that might be suitable test species are the well studied Trioxys indicus Subba Rao and Sharma (Hymenoptera: Aphidiidae) (Singh and Agarwala, 1992) and Aphidius colemani Viereck (Hymenoptera: Braconidae) (Starỳ, 1975). In general, little is known about the arthropods attacking bruchids in storage (Van Huis, 1991). The only parasitoid that has been reported from chickpea samples collected in storage systems in India is Anisopteromalus calandrae (Howard) (Hymenoptera: Pteromalidae) (Devi, 1996). Another parasitoid species that could be deployed in risk assessment studies is Dinarmus basalis (Rondani) (Hymenoptera: Pteromalidae). This species is reported to occur in India and has successfully been reared on chickpea seeds infested with different Callosobruchus spp. (Verma, 1991). Furthemore, both parasitoid species can easily be reared and are well described.

\section{Conclusions}

Insect-resistant GM chickpeas have the potential to reduce current gaps between attainable and actual yields, especially in subsistence farming systems, and to decrease the dependency on pesticides in some circumstances. Benefits will be maximum in the control of $H$. armigera since this pest is difficult to control with conventional methods usually requiring numerous pesticide applications. However, it appears that no single approach will suffice in itself to control $H$. armigera. Pyramiding different insecticidal genes (e.g. Zhang et al., 2000; Burgess et al., 2002) and the integration of transgenics with other components of pest management have to be envisaged (Waage, 1996; Fitt, 2000). The expression of the $\alpha$-amylase inhibitor $\alpha$-AI-1 in chickpea seeds has the potential to give good protection against bruchid attack. But this single resistant gene will need to be supplemented by other methods of pest control since it poses a high selection pressure that is likely to cause the rapid emergence of bruchid strains that are not affected by the inhibitor. It remains to be seen whether aphid-transmitted viral diseases can be controlled by regulating the aphid vector, for example by the deployment of plants that express lectins such as ASAL. The success of this approach will largely depend on the effectiveness of the transgene product and on the nature of the virus such as virulence and the speed at which it is transmitted.

One major obstacle to the deployment of transgenic chickpeas expressing cry genes from Bacillus thuringiensis for the control of $H$. armigera might be the 
development of resistance in the target pest. Susceptible larvae of $H$. armigera are already not very sensitive to Bt-toxins such as CrylAc (Akhurst et al., 2003) when compared to other Lepidoptera and strains with high levels of resistance to this particular Bt-toxin have already been selected (Kranthi et al., 2000; Akhurst et al., 2003). But despite the fact that the deployment of cryl $A c$ expressing $B t$-cotton in China increased from 10,000 ha in 1997 to 1 million ha in 2000, no increase in the resistance of $H$. armigera to Cry1Ac was detected (Wu et al., 2002). Implementing a resistance management plan in a country such as India may be difficult. Since $H$. armigera is a polyphagous pest with a reported number of at least 181 host plants from 45 families in India alone (Manjunath et al., 1989), other hosts that do not produce $B t$-toxins could act as refuges and continuously produce susceptible insects. However, this effect will be lessened when the same Cry toxins (or those with cross-resistance) are expressed in different food plants of this pest. This is for example the case for cryl Ac and crylAb that are expressed in the commercialised $B t$-cotton variety and currently engineered not only in chickpea, but in a number of other crops including pulses, vegetables and cereals (Sharma et al., 2003a). The deployment of these crops would increase the selection pressure on $H$. armigera requiring a more adaptive strategy including effective and sensitive resistance monitoring (Andow, 2002). A preventive measure to delay the development of resistance could be the pyramiding of dissimilar $B t$-toxin genes (Zhao et al., 2003).

Another concern related to the deployment of GM crops is the possible gene flow to non-transformed varieties and wild relatives. However, this risk is low since chickpea is a strong self-pollinator. Pollination occurs when the keel is still closed, 12-24 h before the flower is fully expanded (Ayyar, 1935; Eshel, 1968). In addition, viability of the pollen is decreased when the flowers are fully expanded (Eshel, 1968). Field studies have established that natural out-crossing to other varieties occurs at levels below $1 \%$, probably due to pollen being transported by flower visiting insects (Van Rheenen et al., 1990; Tayyar et al., 1995). Based on this knowledge, an isolation distance of $5 \mathrm{~m}$ for certified seed crops in India has been established (Chowdhury et al., 1991).

Besides concerns relating to environmental and health risks, issues relating to the intellectual property rights and corporate dominance have led to limited acceptance of GM crops among the public and policy-makers in developing countries (Paarlberg, 2001). This could partly be overcome when GM crops are developed in public research institutions. Currently, a number of active plant transformation programmes are in progress in public research institutions in India including ICRISAT. The latter can also play an important role in facilitating technology transfer by fostering NorthSouth partnerships in developing countries (Morris and Hoisington, 2000; Sharma et al., 2003a).

\section{Acknowledgements}

This study was compiled within the Pulse Network of the Indo Swiss Collaboration in Biotechnology (ISCB). Funding by the Swiss Agency for Development and Cooperation (SDC) in Berne, Switzerland, and the Department of Biotechology (DBT) in New Delhi, India, is gratefully acknowledged. We acknowledge the help from A. Das (AAU, Jorhat, India) while preparing the manuscript. We thank F. Bigler (Agroscope FAL Reckenholz, Zurich, Switzerland), T.J.V. Higgins (CSIRO Plant Industry, Canberra, Australia) and T.G. Shanower (USDA-ARS, Sidney, Montana, USA) for discussions and comments made on earlier drafts of the manuscript.

\section{References}

Akhurst, R.J., James, W., Bird, L., Beard, C., 2003. Resistance to the CrylAc $\delta$-endotoxin of Bacillus thuringiensis in the cotton bollworm, Helicoverpa armigera (Lepidoptera: Noctuidae). J. Econ. Entomol. 96, 1290-1299.

Andow, D.A., 2002. Resisting resistance to Bt-corn. In: Letourneau, D.K., Burrows, B.E. (Eds.), Genetically Modified Organisms. Assessing Environmental and Human Health Effects. CRC Press, Boca Raton, FL, USA, pp. 99-124.

Applebaum, S.W., Tadmor, U., Podoler, H., 1970. The effect of starch and a heteropolysaccharide fraction from Phaseolus vulgaris on development and fecundity of Callosobruchus chinensis (Coleoptera-Bruchidae). Entomol. Exp. Appl. 13, 61-70.

Armes, N.J., Jadhav, D.R., DeSouza, K.R., 1996. A survey of insecticide resistance in Helicoverpa armigera in the indian subcontinent. Bull. Entomol. Res. 86, 499-514.

Atkinson, H.J., Green, J., Cowgill, S.E., Levesley, A., 2001. The case for genetically modified crops with a poverty focus. Trends Biotechnol. 19, 91-96.

Ayyar, V.R., 1935. Anthesis and pollination in bengal gram (Cicer arietinum). Madras Agric. J. 23, 170-178.

Bandyopadhyay, S., Roy, A., Das, S., 2001. Binding of garlic (Allium sativum) leaf lectin to the gut receptors of homopteran pests is correlated to its insecticidal activity. Plant Sci. 161, $1025-1033$.

Barna, K.S., Wakhlu, A.K., 1993. Somatic embryogenesis and plant regeneration from callus cultures of chickpea (Cicer arietinum $\mathrm{L}$ ). Plant Cell Rep. 12, 521-524.

Barna, K.S., Wakhlu, A.K., 1994. Whole plant regeneration from Cicer arietinum from callus cultures via organogenesis. Plant Cell Rep. 13, 510-513.

Bernal, C.C., Aguda, R.M., Cohen, M.B., 2002. Effect of rice lines transformed with Bacillus thuringiensis toxin genes on the brown planthopper and its predator Cyrtorhinus lividipennis. Entomol. Exp. Appl. 102, 21-28.

Bhatnagar, R., Shukla, Y.M., Shukla, B.B., Patel, J.C., Talali, J.G., 2000. Biochemical composition of susceptible and tolerant genotypes of chickpea for pod borer. Indian J. Pulses Res. 13, $58-59$. 
Boeke, S.J., van Loon, J.J.A., van Huis, A., Kossou, D.K., Dicke, M., 2001. The use of plant material to protect stored leguminous seeds against seed beetles: a review. Wageningen University Papers 01.3.

Bown, D.P., Wilkinson, H.S., Gatehouse, J.A., 1997. Differentially regulated inhibitor-sensitive and insensitive protease genes from the phytophagous insect pest, Helicoverpa armigera, are members of complex multigene families. Insect Biochem. Mol. Biol. 27, 625-638.

Bruinsma, M., Kowalchuk, G.A., van Veen, J.A., 2003. Effects of genetically modified plants on microbial communities and processes in soil. Biol. Fertil. Soils 37, 329-337.

Brunt, A.A., Crabtree, K., Dallwitz, M.J., Gibbs, A.J., Watson, L., Zurcher, E.J. (Eds.), 1996. Plant Viruses Online: Descriptions and Lists from the VIDE Database. Version: 20th August 1996. http:// image.fs.uidaho.edu/vide/refs.htm

Burgess, E.P.J., Malone, L.A., Christeller, J.T., Lester, M.T., Murray, C., Philip, B.A., Phung, M.M., Tregidga, E.L., 2002. Avidin expressed in transgenic tobacco leaves confers resistance to two noctuid pests, Helicoverpa armigera and Spodoptera litura. Transgen. Res. 11, 185-198.

Campos, F.A.P., Xavier-Filho, J., Silva, C.P., Ary, M.B., 1989. Resolution and partial characterization of proteinases and $\alpha$ amylases from midguts of larvae of the bruchid beetle Callosobruchus maculatus (F.). Comp. Biochem. Physiol. 92B, 51-57.

Candolfi, M.P., Barrett, K.L., Cambell, P.J., Forster, R., Grandy, N., Huet, M.-C., Lewis, G., Oomen, P.A., Schmuck, R., Vogt, H., 2001. Guidance document on regulatory testing and risk assessment procedures for plant protection products with non-target arthropods. ESCORT 2 Workshop held in Wageningen, The Netherlands. SETAC, Pensacola, FL, USA, 46 pp.

Carlini, C.R., Oliveira, A.E.A., Azambuja, P., Xavier, J., Wells, M.A., 1997. Biological effects of canatoxin in different insect models: evidence for a proteolytic activation of the toxin by insect cathepsinlike enzymes. J. Econ. Entomol. 90, 340-348.

Chakrabarti, S.K., Mandaokar, A.D., Kumar, P.A., Sharma, R.P., 1998a. Efficacy of lepidopteran specific $\delta$-endotoxins of Bacillus thuringiensis against Helicoverpa armigera. J. Inv. Pathol. 72, 336-337.

Chakrabarti, S.K., Mandaokar, A.D., Kumar, P.A., Sharma, R.P., 1998b. Synergistic effect of Cry1 Ac and Cry1F delta-endotoxins of Bacillus thuringiensis on cotton bollworm, Helicoverpa armigera. Curr. Sci. 75, 663-664.

Chakrabarti, S.K., Mandaokar, A.D., Shukla, A., Pattanayak, D., Naik, P.S., Sharma, R.P., Kumar, P.A., 2000. Bacillus thuringiensis $\mathrm{Cry} 1 \mathrm{Ab}$ gene confers resistance to potato against Helicoverpa armigera (Hubner). Potato Res. 43, 143-152.

Charity, J.A., Anderson, M.A., Bittisnich, D.J., Whitecross, M., Higgins, T.J.V., 1999. Transgenic tobacco and peas expressing a proteinase inhibitor from Nicotiana alata have increased insect resistance. Mol. Breed. 5, 357-365.

Cherry, A.J., Rabindra, R.J., Parnell, M.A., Geetha, N., Kennedy, J.S., Grzywacz, D., 2000. Field evaluation of Helicoverpa armigera nucleopolyhedrovirus formulations for control of the chickpea pod-borer, $H$ armigera (Hubn.), on chickpea (Cicer arietinum var. Shoba) in southern india. Crop Prot. 19, 51-60.

Chowdhury, R.K., Punia, R.C., Tomar, R.P.S., 1991. Isolation requirements in chickpea seed production. Int. Chickpea Newsl. 25,8 .

Chrispeels, J., Grossi de Sa, M.F., Higgins, T.J.V., 1998. Genetic engineering with $\alpha$-amylase inhibitors makes seeds resistant to bruchids. Seed Sci. Res. 8, 257-263.

Christeller, J.T., Burgess, E.P.J., Mett, V., Gatehouse, H.S., Markwick, N.P., Murray, C., Malone, L.A., Wright, M.A., Philip, B.A., Watt, D., Gatehouse, L.N., Lövei, G.L., Shannon, A.L., Phung, M.M., Watson, L.M., Laing, W.A., 2002. The expression of a mammalian proteinase inhibitor, bovine spleen trypsin inhibitor in tobacco and its effects on Helicoverpa armigera larvae. Transgen. Res. 11, 161-173.

Coll, M., Guershon, M., 2002. Omnivory in terrestrial arthropods: mixing plant and prey diets. Annu. Rev. Entomol. 47, 267-297.

Conner, A.J., Glare, T.R., Nap, J.-P., 2003. The release of genetically modified crops into the environment. Part II. Overview of ecological risk assessment. Plant J. 33, 19-46.

Cowgill, S.E., Bhagwat, V.R., 1996. Comparison of the efficacy of chemical control and Helicoverpa NPV for the management of Helicoverpa armigera (Hubner) on resistant and susceptible chickpea. Crop Prot. 15, 241-246.

Cowgill, S.E., Lateef, S.S., 1996. Identification of antibiotic and antixenotic resistance to Helicoverpa armigera (Lepidoptera: Noctuidae) in chickpea. J. Econ. Entomol. 89, 224-229.

CPC, 2001. Crop Protection Compendium, Global Module, 3rd Edition. CAB International, Wallingford, UK

Cubero, J.I., 1987. Morphology of chickpea. In: Saxena, M.C., Singh, K.B. (Eds.), The Chickpea. CAB International, Wallingford, UK, pp. 35-66.

Dale, P.J., Clarke, B., Fontes, E.M.G., 2002. Potential for the environmental impact of transgenic crops. Nature Biotech. 20, $567-574$

Das, A., Sarmah, B.K., Modi, M.K., Deka, P.C., 2002. Transformation of chickpea (Cicer arietinum L.) for resistance against storage pest Callosobruchus spp. Proceedings of Biohorizon 2002. Fourth National Symposium on Biochemical Engineering and Biotechnology, Indian Institute of Technology, New Delhi, March 1-2, 2002, pp. 174-176.

Dasgupta, I., Malathi, V.G., Mukhrjee, S.K., 2003. Genetic engineering for virus resistance. Curr. Sci. 84, 341-354.

Devi, N., 1996. Occurrence of parasitoid, Anisopteromalus calandrae (Howard) on bruchid, Callosobruchus chinensis Linn. infesting gram (Cicer arietinum L.). J. Entomol. Res. 20, 87-88.

Dhingra, S., 1994. Development of resistance in the bean aphid, Aphis craccivora Koch. to various insecticides used for nearly a quarter century. J. Entomol. Res. 18, 105-108.

Dias, C.A.R., Yadav, T.D., 1988. Incidence of pulse beetles in different legume seeds. Indian J. Entomol. 50, 457-461.

Dineshkumar, V., Kirti, P.B., Sachan, J.K.S., Chopra, V.L., 1994. Plant regeneration via somatic embryogenesis in chickpea (Cicer arietinum L.). Plant Cell Rep. 13, 468-472.

Down, R.E., Gatehouse, A.M.R., Hamilton, W.D.O., Gatehouse, J.A., 1996. Snowdrop lectin inhibits development and decreases fecundity of the glasshouse potato aphid (Aulacorthum solani) when administered in vitro and via transgenic plants both in laboratory and glasshouse. J. Insect Physiol. 42, 1035-1045.

Dutton, A., Romeis, J., Bigler, F., 2003. Assessing the risks of insect resistant transgenic plants for beneficial arthropods: $\mathrm{Bt}$ maize expressing Cry1 Ab as a case study. BioControl 48, 611-636.

Eshel, Y., 1968. Flower development and pollen viability of chickpea. Israel J. Agric. Res. 18, 31-33.

FAO (2003). FAOSTAT, Agriculture. Food and Agriculture Organization of the United Nations. Rome, Italy (http://apps.fao.org).

Fauquet, C.M., Stanley, J., 2003. Geminivirus classification and nomenclature: progress and problems. Ann. Appl. Biol. 142, $165-189$.

Fitt, G.P., 1989. The ecology of Heliothis armigera in relation to agroecosystems. Annu. Rev. Entomol. 34, 17-52.

Fitt, G.P., 2000. An Australian approach to IPM in cotton: integrating new technologies to minimise insecticide dependence. Crop Prot. 19, 793-800.

Foissac, X., Nguyen Thi Loc, Christou, P., Gatehouse, A.M.R., Gatehouse, J.A., 2000. Resistance to green leafhopper (Nephotettix virescens) and brown plant hopper (Nilaparvata lugens) in transgenic rice expressing snowdrop lectin (Galanthus nivalis agglutinin; GNA). J. Insect Physiol. 46, 573-583. 
Fontana, G.S., Santini, L., Caretto, S., Frugis, G., Mariotti, D., 1993. Genetic transformation in the grain legume Cicer arietinum L. (chickpea). Plant Cell Rep. 12, 194-198.

Franco, O.L., Rigde, D.J., Melo, F.R., Grossi-de-Sá, M.F., 2002. Plant $\alpha$-amylase inhibitors and their interaction with insect $\alpha$-amylases: structure, function and potential for crop protection. Eur. J. Biochem. 269, 397-412.

Gatehouse, A.M.R., Boulter, D., 1983. Assessment of the antimetabolic effects of trypsin inhibitors from cowpea (Vigna unguiculata) and other legumes on development of the bruchid beetle Callosobruchus maculatus. J. Sci. Food. Agric. 34, 345-350.

Gatehouse, A.M.R., Butler, K.J., Fenton, K.A., Gatehouse, J.A., 1985. Presence and partial characterisation of a major protelytic enzyme in the larval gut of Callosobruchus maculatus. Entomol. Exp. Appl. 39, 279-286.

Gatehouse, A.M.R., Howe, D.S., Flemming, J.E., Hilder, V.A., Gatehouse, J.A., 1991. Biochemical basis of insect resistance in winged beans (Psophocarpus tetragonolobus) seeds. J. Sci. Food. Agric. 55, 63-74.

Gatehouse, A.M.R., Down, R.E., Powell, K.S., Sauvion, N., Rahbé, Y., Newell, C.A., Merryweather, A., Hamilton, W.D.O., Gatehouse, J.A., 1996. Transgenic potato plants with enhanced resistance to the peach-potato aphid Myzus persicae. Entomol. Exp. Appl. 79, 295-307.

Gatehouse, L.N., Shannon, A.L., Burgess, E.P.J., Christeller, J.T., 1997. Characterization of major midgut proteinase cDNAs from Helicoverpa armigera larvae and changes in gene expression in response to four proteinase inhibitors in the diet. Insect Biochem. Molec. Biol. 27, 929-944.

Gatehouse, L.N., Christeller, J.T., Gatehouse, H.S., Zou, X.Y., 2002. A strong inhibitor of chymotrypsin/elastase is highly antimetabolic to Helicoverpa armigera larvae. New Zealand Plant Prot. 55, 421-428.

Giri, A.P., Harsulkar, A.M., Deshpande, V.V., Sainani, M.N., Gupta, V.S., Ranjekar, P.K., 1998. Chickpea defensive proteinase inhibitors can be inactivated by podborer gut proteinases. Plant Physiol. 116, 393-401.

Godbole, S.A., Krishna, T.G., Bhatia, C.R., 1994. Further characterisation of protease inhibitors from pigeon pea (Cajanus cajan (L) Millsp) seeds. J. Sci. Food Agric. 64, 331-335.

Gould, F., 1994. Potential and problems with high-dose strategies for pesticidal engineered crops. Biocontr. Sci. Technol. 4, 451-461.

Gould, F., Kennedy, G.G., Johnson, M.T., 1991. Effects of natural enemies on the rate of herbivore adaption to resistant host plants. Entomol. Exp. Appl. 58, 1-14.

Habibi, J., Backus, E.A., Czapla, T.H., 1993. Plant lectins affect survival of the potato leafhopper (Homoptera: Cicadellidae). J. Econ. Entomol. 86, 945-951.

Harsulkar, A.M., Giri, A.P., Patankar, A.G., Gupta, V.S., Sainani, M.N., Ranjekar, P.K., Deshpande, V.V., 1999. Successive use of non-host plant proteinase inhibitors required for effective inhibition of gut proteinases and larval growth of Helicoverpa armigera. Plant Physiol. 121, 497-506.

Head, G., Brown, C.R., Groth, M.E., Duan, J.J., 2001. CrylAb protein levels in phytophagous insects feeding on transgenic corn: implications for secondary exposure risk assessment. Entomol. Exp. Appl. 99, 37-45.

Hickson, R., Moeed, A., Hannah, D., 2000. HSNO, ERMA and risk management. New Zealand Sci. Rev. 57, 72-77.

Hilder, V.A., Boulter, D., 1999. Genetic engineering of crop plants for insect resistance - a critical review. Crop Prot. 18, 177-191.

Hill, R.A., Sendashonga, C., 2003. General principles for risk assessment of living modified organisms: lessons from chemical risk assessment. Environ. Biosafety Res. 2, 81-88.

Horn, N.M., 1994. Viruses involved in chickpea stunt. Ph.D. Thesis, Wageningen Agricultural University, Wageningen, The Netherlands.
Horn, N.M., Reddy, S.V., Reddy, D.V.R., 1994. Virus-vector relationships of chickpea chlorotic dwarf geminivirus and the leafhopper Orosius orientalis (Hemiptera, Cicadellidae). Ann. Appl. Biol. 124, 441-450.

Horn, N.M., Reddy, S.V., Reddy, D.V.R., 1995. Assessment of yield losses caused by chickpea chlorotic dwarf geminivirus in chickpea (Cicer arietinum) in India. European J. Plant Pathol. 101, 221-224.

Huesing, J.E., Murdock, L.L., Shade, R.E., 1991a. Rice and stinging nettle lectins: insecticidal activity similar to wheat germ agglutinin. Phytochemistry 30, 3565-3568.

Huesing, J.E., Murdock, L.L., Shade, R.E., 1991b. Effect of wheat germ isolectins on development of cowpea weevil. Phytochemistry 30, 785-788.

ICRISAT, 1992. The Medium Term Plan. International Crops Research Institute for the Semi-Arid Tropics. Patancheru, Andhra Pradesh, India.

Ishimoto, M., Kitamura, K., 1989. Growth inhibitory effects of an $\alpha$-amylase inhibitor from kidney bean Phaseolus vulgaris $\mathrm{L}$. on three species of bruchids (Bruchidae, Coleoptera). Appl. Entomol. Zool. 24, 281-286.

Ishimoto, M., Sato, T., Chrispeels, M.J., Kitamura, K., 1996. Bruchid resistance of transgenic adzuki bean expressing seed $\alpha$-amylase inhibitor of common bean. Entomol. Exp. Appl. 79, 309-315.

Jalali, S.K., Singh, S.P., Kumar, P., Ballal, C.R., 1988. Influence of the food plants on the degree of parasitism of larvae of Heliothis armigera by Cotesia kazak. Entomophaga 33, 65-71.

Jalali, S.K., Mohan, K.S., Singh, S.P., Manjunath, T.M., Lalitha, Y., 2004. Baseline-susceptibility of the old-world bollworm, Helicoverpa armigera (Hübner) (Lepidoptera: Noctuidae) populations from india to Bacillus thuringiensis CrylAc insecticidal protein. Crop Prot. 23, 53-59.

James, C., 2002. Global review of commercialized transgenic crops: 2001. Feature: Bt-cotton. ISAAA Briefs No. 26, ISAAA, Ithaca, NY, USA.

Jayanand, B., Sudarsanam, G., Sharma, K.K., 2003. An efficient protocol for regeneration of whole plant of chickpea (Cicer arietinum L.) by using axillary meristem explant derived from in vitro germinated seedlings. In vitro Cell. Dev. Biol.-Plant 39, 171-179.

Jenkins, N.E., Grzywacz, D., 2000. Quality control of fungal and viral biocontrol agents - assurance of product performance. Biocontr. Sci. Technol. 10, 753-777.

Jodha, N.S., Subba Rao, K.V., 1987. Chickpea: world importance and distribution. In: Saxena, M.C., Singh, K.B. (Eds.), The Chickpea. CAB International, Wallingford, UK, pp. 1-10.

Johnston, K.A., Lee, M.J., Gatehouse, J.A., Anstee, J.H., 1991. The partial purification and characterisation of serine protease activity in midgut of larval Helicoverpa armigera. Insect Biochem. 21, 389-397.

Johnston, K.A., Gatehouse, J.A., Anstee, J.H., 1993. Effects of soybean protease inhibitors on the growth and development of larval Helicoverpa armigera. J. Insect Physiol. 39, 657-664.

Jongsma, M.A., Bolter, C.J., 1997. The adaptation of insects to plant protease inhibitors. J. Insect Physiol. 43, 885-895.

Joshi, S., Venkatesan, T., Rao, N.S., 1997. Host range and predatory fauna of Aphis craccivora koch (Homoptera: Aphididae) in Bangalore, Karnataka. J. Biol. Contr. 11, 59-63.

Kaiser, W.J., Ghanekar, A.M., Nene, Y.L., Rao, B.S., Anjaiah, V., 1990. Viral diseases of chickpea. In: Chickpea in the Nineties. Proceedings of the Second International Workshop on Chickpea Improvement. 4-8 December 1989, ICRISAT, Patancheru, Andhra Pradesh, India, pp. 139-142.

Kanrar, S., Venkateswari, J., Kirti, P.B., Chopra, V.L., 2002. Transgenic indian mustard (Brassica juncea) with resistance to the mustard aphid (Lipaphis erysimi Kalt.). Plant Cell Rep. 20, 976-981. 
Kar, S., Johnson, T.M., Nayak, P., Sen, S.K., 1996. Efficient transgenic plant regeneration through Agrobacterium-mediated transformation of chickpea (Cicer arietinum L.). Plant Cell Rep. $16,32-37$.

Kar, S., Basu, D., Sampa Das, Ramkrishnan, N.A., Mukherjee, P., Nayak, P., Sen, S.K., 1997. Expression of Cryl A(c) gene of Bacillus thuringiensis in transgenic chickpea plants inhibits development of pod borer (Heliothis armigera) larvae. Transgen. Res. 6, 177-185.

Kennedy, G.G., 1976. Host plant resistance and the spread of plant viruses. Environ. Entomol. 5, 827-832.

Kowalchuk, G.A., Bruinsma, M., van Veen, J.A., 2003. Assessing responses of soil microorganisms to GM plants. Trends Ecol. Evol. 18, 403-410.

Kranthi, K.R., Kranthi, S., Ali, S., Banerjee, S.K., 2000. Resistance to 'Cry1Ac $\delta$-endotoxin of Bacillus thuringiensis' in a laboratory selected strain of Helicoverpa armigera (Hubner). Curr. Sci. 78, 1001-1004.

Kranthi, K.R., Kranthi, S., Wanjari, R.R., 2001. Baseline toxicity of CrylAb toxins to Helicoverpa armigera (Hubner) (Lepidoptera: Noctuidae) in India. Int. J. Pest Manage. 47, 141-145.

Krishnamurthy, K.V., Suhasini, K., Sagare, A.P., Meixner, M., de Kathen, A., Pickardt, T., Schieder, O., 2000. Agrobacterium mediated transformation of chickpea (Cicer arietinum L.) embryo axes. Plant Cell Rep. 19, 235-240.

Kumar, H., Kumar, V., 2004. Tomato expressing Cry1A(b) insecticidal protein from Bacillus thuringiensis protected against tomato fruit borer, Helicoverpa armigera (Hubner) (Lepidoptera: Noctuidae) damage in the laboratory, greenhouse and field. Crop. Prot. 23, 135-139.

Kumar, P.A., Mandaokar, A., Sreenivasu, K., Chakrabarti, S.K., Bisaria, S., Sharma, S.R., Kaur, S., Sharma, R.P., 1998. Insectresistant transgenic brinjal plants. Mol. Breed. 4, 33-37.

Kuroda, M., Ishimoto, M., Suzuki, K., Kondo, H., Abe, K., Kitamura, K., Arai, S., 1996. Oryzacystatins exhibit growthinhibitory and lethal effects on different species of bean insect pests Callosobruchus chinensis (Coleoptera) and Riptortus clavatus (Hemiptera). Biosci. Biotechnol. Biochem 60, 209-212.

Lal, A.K., Dikshit, A.K., 2001. The protection of chickpea (Cicer arietinum $\mathrm{L}$.) during storage using deltamethrin on sacks. Pesticide Res. J. 13, 27-31.

Lateef, S.S., 1985. Gram pod borer (Heliothis armigera) (Hub.) resistance in chickpea. Agric. Ecosyst. Environ. 14, 95-102.

Lateef, S.S., Sachan, J.N., 1990. Host-plant resistance to Helicoverpa armigera in different agroecological contexts. In: Chickpea in the Nineties. Proceedings of the Second International Workshop on Chickpea Improvement. 4-8 December 1989, ICRISAT, Patancheru, Andhra Pradesh, India, pp. 181-189.

Liao, C., Heckel, D.G., Akhurst, R., 2002. Toxicity of Bacillus thuringiensis insecticidal proteins for Helicoverpa armigera and Helicoverpa punctigera (Lepidoptera: Noctuidae), major pests of cotton. J. Inv. Pathol. 80, 55-63.

Lingappa, S., Hegde, R., 2001. Exploitation of biocontrol potential in the management of insect pests of pulse crops. In: Upadhyay, R.K., Mukerji, K.G., Chamola, B.P. (Eds.), Biocontrol Potential and its Exploitation in Sustainable Agriculture, Volume 2: Insect Pests. Kluwer Academic/Plenum Publishers, New York, USA, pp. 321-344.

Macedo, M.L.R., Anrade, L.B.D.S., Moraes, R.A., Xavier-Filho, J., 1993. Vicilin variants and resistance of cowpea (Vigna unguiculata) seeds to the cowpea weevil (Callosobruchus maculatus). Comp. Biochem. Physiol. 105C, 89-94.

Macedo, M.L.R., Coelho, M.B., Freire, M.G.M., Machado, O.L.T., Marangoni, S., Novello, J.C., 2000. Effect of a toxic protein isolated from Zea mays seeds on the development and survival of the cowpea weevil, Callosobruchus maculatus. Protein Pept. Lett. $17,25-31$.
Macedo, M.L.R., Mello, G.C., Freire, M.G.M., Novello, J.C., Marangoni, S., de Matos, D.G.G., 2002a. Effect of a trypsin inhibitor from Dimorphandra mollis seeds on the development of Callosobruchus maculatus. Plant Physiol. Biochem. 40, 891-898.

Macedo, M.L.R., Freire, M.G.M., Novello, J.C., Marangoni, S., 2002b. Telisia esculenta lectin and larval development of Callosobruchus maculatus and Zabrotes subfasciatus (Coleoptera: Bruchidae). Biochim. Biophys. Acta 1571, 83-88.

Machuka, J.S., Okeola, O.G., Chrispeels, M.J., Jackai, L.E.N., 2000. The african yam bean seed lectin affects the development of the cowpea weevil but does not affect the development of larvae of the legume pod borer. Phytochemistry 53, 667-674.

Maiti, R.K., 2001. The chickpea crop. In: Maiti, R., Wesche-Ebeling, P. (Eds.), Advances in Chickpea Science. Science Publishers Inc., Enfield, USA, pp. 1-31.

Malone, L.A., Pham-Delègue, M.-H., 2001. Effects of transgene products on honey bees (Apis mellifera) and bumblebees (Bombus sp). Apidologie 32, 287-304.

Mandaokar, A.D., Goyal, R.K., Shukla, A., Bisaria, S., Bhalla, R., Reddy, V.S., Chaurasia, A., Sharma, R.P., Altosaar, I., Kumar, P.A., 2000. Transgenic tomato plants resistant to fruit borer (Helicoverpa armigera Hubner). Crop Prot. 19, 307-312.

Manjunath, T.M., Bhatnagar, V.S., Pawar, C.S., Sithanantham, S., 1989. Economic importance of Heliothis spp. in India and an assessment of their natural enemies and host plants. In: King, E.G., Jackson, R.D. (Eds.), Proceedings of the Workshop on Biological Control of Heliothis: Increasing the Effectiveness of Natural Enemies. Far Eastern Regional Research Office, United States Department of Agriculture, New Delhi, India, pp. 197-228.

Mehto, D.N., Singh, K.M., Singh, R.N., 1986. Natural enemy complex on insect pest complex in chickpea Cicer arietinum Linn. Bull. Entomol. 27, 1-12.

Mookherjee, P.B., Jotwani, M.G., Yadav, T.D., Sircar, P., 1970. Studies on incidence and extend of damage due to insect pests in stored seeds-II. Leguminous and vegetable seeds. Indian J. Entomol. 32, 350-355.

Moreno, J., Chrispeels, M.J., 1989. A lectin gene encodes the $\alpha$ amylase inhibitor of the common bean. Proc. Natl. Acad. Sci. USA 86, 7885-7889.

Morris, M.L., Hoisington, D., 2000. Bringing the benefits to the poor: the role of the CGIAR centers. In: Qaim, M., Krattiger, A.F., von Braun, J. (Eds.), Agricultural Biotechnology in Developing Countries: Towards Optimizing the Benefits for the Poor. Kluwer Academic Publishers, Boston, USA, pp. 327-355.

Morton, R.L., Schroeder, H.E., Bateman, K.S., Chrispeels, M.J., Armstrong, E., Higgins, T.J.V., 2000. Bean $\alpha$-amylase inhibitor 1 in transgenic peas (Pisum sativum) provides complete protection from pea weevil (Bruchus pisorum) under field conditions. Proc. Natl. Acad. Sci. USA 97, 3820-3825.

Muehlbauer, F.J., Singh, K.B., 1987. Genetics of chickpea. In: Saxena, M.C., Singh, K.B. (Eds.), The Chickpea. CAB International, Wallingford, UK, pp. 99-125.

Murdock, L.L., Shade, R.E., Pomeroy, M.A., 1988. Effects of E-64, a cysteine proteinase inhibitor, on cowpea weevil growth, development and fecundity. Environ. Entomol. 17, 467-469.

Murdock, L.L., Huesing, J.E., Nielsen, S.S., Pratt, R.C., Shade, R.E., 1990. Biological effects of plant lectins on the cowpea weevil. Phytochemistry 29, 85-89.

Murugan, K., Senthil, K.N., Jeyabalan, D., Senthil, N.S., Sivaramakrishnan, S., Swamiappan, M., 2000. Influence of Helicoverpa armigera (Hübner) diet on its parasitoid Campoletis chlorideae Uchida. Insect Sci. Applic. 20, 23-31.

Murray, D.A.H., Rynne, K.P., 1994. Effect of host plant on parasitism of Helicoverpa armigera (Lep.: Noctuidae) by Microplitis demolitor (Hym.: Braconidae). Entomophaga 39, 251-255. 
Nandeesha, P., Prasad, D.T., 2001. Characterization of serine proteinase inhibitor from subabul (Leucaena leucocephala Lam) seeds. J. Plant Biochem. Biotech. 10, 75-78.

Nandi, A.K., Basu, D., Sampa Das, Sen, S.K., 1999. High level expression of soybean trypsin inhibitor gene in transgenic tobacco plants failed to confer resistance against damage by Helicoverpa armigera. J. Biosci. 24, 445-452.

Nikam, P.K., Gaikwad, A.M., 1991. Effect of host larvae of Helicoverpa armigera Hübner on the parasitising ability of Campoletis chlorideae Uchida. Entomon 16, 301-303.

Niknejad, M., Khosh-Khui, M., 1972. Natural cross-pollination in gram (Cicer arietinum L.). Indian J. Agric. Sci. 42, 273-274.

Oliveira, A.S., Lima, L.M., Pereira, R.A., Morais, A.H.A., Pereira, L.S., Sales, M.P., 2001a. The performance of Callosobruchus maculates F. in artificial seeds containing proteins from Prosopis juliflora seeds. Protein Pept. Lett. 8, 225-229.

Oliveira, A.E.A., Sassaki, G.L., Lacomini, M., da Cunha, M., Gomes, V.M., Fernandes, B.K.V.S., Xavier-Filho, J., $2001 \mathrm{~b}$. Isolation and characterization of a galactorhamnan polysaccharide from the seed coat of Canavalia ensiformis that is toxic to the cowpea weevil (Callosobruchus maculatus). Entomol. Exp. Appl. 101, 225-231.

Oliveira, A.S., Pereira, R.A., Lima, L.M., Morais, A.H.A., Melo, F.R., Franco, O.L., Bloch Jr, C., Grossi-de-Sá, M.F., Sales, M.P., 2002. Activity toward bruchid pest of a Kunitz-type inhibitor from seeds of the Algaroba tree (Prosopis juliflora D.C.). Pestic. Biochem. Phys. 72, 122-132.

Paarlberg, R.L., 2001. The Politics of Precaution. Genetically Modified Crops in Developing Countries. Johns Hopkins Press, Baltimore and London.

Patankar, A.G., Harsulkar, A.M., Giri, A.P., Gupta, V.S., Sainani, M.N., Ranjekar, P.K., Deshpande, V.V., 1999. Diversity in inhibitors of trypsin and Helicoverpa armigera gut proteinases in chickpea (Cicer arietinum) and its wild relatives. Theor. Appl. Genet. 99, 719-726.

Patankar, A.P., Giri, A.P., Harsulkar, A.M., Sainani, M.N., Deshpande, V.V., Ranjekar, P.K., Gupta, V.S., 2001. Complexity in specificities and expression of Helicoverpa armigera gut proteinases explains polyphagous nature of the insect pest. Insect Biochem. Mol. Biol. 31, 453-464.

Payne, J.M., Cannon, R.J.C., 1993. Use of Bacillus thuringiensis isolates for controlling pests in the family Aphididae. United States Patent No. 5,262,159.

Peumans, W.J., van Damme, E.J.M., 1995. Lectins as plant defense proteins. Plant Physiol. 109, 347-352.

Powell, K.S., Gatehouse, A.M.R., Hilder, V.A., Gatehouse, J.A., 1995. Antifeedant effects of plant lectins and an enzyme on the adult stage of the rice brown planthopper, Nilaparvata lugens. Entomol. Exp. Appl. 75, 51-59.

Prins, M., 2003. Broad virus resistance in transgenic plants. Trends in Biotech. 21, 373-375.

Quaim, M., Zilberman, D., 2003. Yield effects of genetically modified crops in developing countries. Science 299, 900-902.

Rabindra, R.J., Sathiah, N., Jayaraj, S., 1992. Efficacy of nuclear polyhedrosis virus against Helicoverpa armigera $(\mathrm{Hbn})$ on Helicoverpa-resistant and susceptible varieties of chickpea. Crop Prot. 11, 320-322.

Raghuram, N., 2002. Indian plant biology enters the biotechnology era. Trends Plant Sci. 7, 92-94.

Rahbé, Y., Sauvion, N., Febvay, G., Peumans, W.J., Gatehouse, A.M.R., 1995. Toxicity of lectins and processing of ingested proteins in the pea aphid Acyrthosiphon pisum. Entomol. Exp. Appl. 76, 143-155.

Rahbé, Y., Deraison, C., Bonadé-Bottino, M., Girard, C., Nardon, C., Jouanin, L., 2003. Effects of the cysteine protease inhibitor oryzacystatin (OC-I) on different aphids and reduced performance of Myzus persicae on OC-I expressing transgenic oilseed rape. Plant Sci. 164, 441-450.

Rahman, Md.M., Yadav, T.D., 1987. Toxicity of solutions and dusts of four synthetic pyrethroids against Callosobruchus maculatus Fab. and C. chinensis Linn. Indian J. Entomol. 49, 137-144.

Raina, A.K., 1971. Comparative resistance to three species of Callosobruchus in a strain of chickpea (Cicer arietinum L.). J. Stored Prod. Res. 7, 213-216.

Rao, B.G., Chopra, V.L., 1989. Regeneration in chickpea (Cicer arietinum L.) through somatic embryogenesis. J. Plant Physiol. 134, 637-638.

Raynolds, D., Armes, N.J., 1994. When insecticides fail: the case of the cotton bollworm in india. In: Cartwright, A. (Ed.), World Agriculture 1994. Sterling, London, UK, pp. 39-42.

Reed, W., Cardona, C., Sithanantham, S., Lateef, S.S., 1987. The chickpea insect pests and their control. In: Saxena, M.C., Singh, K.B. (Eds.), The Chickpea. CAB International, Wallingford, UK, pp. 283-318.

Romeis, J., Shanower, T.G., 1996. Arthropod natural enemies of Helicoverpa armigera (Hübner) (Lepidoptera: Noctuidae) in India. Biocontr. Sci. Technol. 6, 481-508.

Romeis, J., Shanower, T.G., Zebitz, C.P.W., 1999. Why Trichogramma (Hymenoptera: Trichogrammatidae) egg parasitoids of Helicoverpa armigera (Lepidoptera: Noctuidae) fail on chickpea. Bull. Entomol. Res. 89, 89-95.

Romeis, J., Babendreier, D., Wäckers, F.L., 2003. Consumption of snowdrop lectin (Galanthus nivalis agglutinin) causes direct effects on adult parasitic wasps. Oecologia 134, 528-536.

Roy, A., Banerjee, S., Mjumder, P., Sampa Das, 2002. Efficiency of mannose-binding plant lectins in controlling a homopteran insect, the red cotton bug. J. Agric. Food Chem. 50, 6775-6779.

Ryan, C.A., 1990. Protease inhibitors in plants: genes for improving defenses against insects and pathogens. Annu. Rev. Phytopathol. $28,425-449$.

Sachan, J.N., 1992. Present status of Helicoverpa armigera in pulses and strategies for its management. In: Sachan, J.N. (Ed.), Helicoverpa Management: Current Status and Future Strategies, Proceedings of First National Workshop. Directorate of Pulses Research, Kanpur, Uttar Pradesh, India, pp. 7-23.

Sagare, A.P., Suhasini, K., Krishnamurthy, K.V., 1993. Plant regeneration via somatic embryogenesis in chickpea (Cicer arietinum L.). Plant Cell Rep. 12, 652-655.

Sarmah, B.K., Moore, A., Tate, W., Molvig, L., Morton, R.L., Rees, D.P., Chiaiese, P., Chrispeels, M.J., Tabe, L.M., Higgins, T.J.V., 2004. Transgenic chickpea seeds expressing high levels of a bean $\alpha$ amylase inhibitor. Mol. Breed., in press.

Sauvion, N., Rahbé, Y., Peumans, W.J., van Damme, E.J.M., Gatehouse, J.A., Gatehouse, A.M.R., 1996. Effects of GNA and other mannose binding lectins on development and fecundity of the peach-potato aphid Myzus persicae. Entomol. Exp. Appl. 79, 285-293.

Sauvion, N., Charles, H., Febvay, G., Rahbé, Y., 2004. Effects of jackbean lectin (ConA) on the feeding behaviour and kinetics of intoxification of the pea aphid, Acyrthosiphon pisum. Entomol. Exp. Appl. 110, 31-44.

Saxena, H., Ahmed, R., 1997. Field evaluation of Beauveria bassiana against Helicoverpa armigera (Hübner) infecting chickpea. J. Biol. Contr. 11, 93-96.

Saxena, H.P., Sircar, P., Phokela, A., 1970. Predation of Coccinella septempunctata Linnaeus and Ischiodon scutellaris Fabricius on Aphis craccivora Koch. Indian J. Entomol. 32, 105-106.

Schalk, J.M., Evans, K.H., Kaiser, W.J., 1973. Resistance in lines of chickpea to attack by Callosobruchus maculatus in Iran. FAO Plant Prot. Bull. 21, 126-131. 
Schillberg, S., Zimmermann, S., Zhang, M.-Y., Fischer, R., 2001. Antibody-based resistance to plant pathogens. Transgen. Res. 10, $1-12$.

Schmuck, R., Candolfi, M.P., Kleiner, R., Mead-Briggs, M., Moll, M., Kemmeter, F., Jans, D., Waltersdorfer, A., Wilhelmy, H., 2000. A laboratory test system for assessing effects of plant protection products on the plant dwelling insect Coccinella septempunctata $\mathrm{L}$. (Coleoptera: Coccinellidae). In: Candolfi, M.P., Blümel, S., Forster, R., Bakker, F.M., Grimm, C., Hassan, S.A., Heimbach, U., Mead-Briggs, M.A., Reber, B., Schmuck, R., Vogt, H. (Eds.), Guidelines to Evaluate Side-Effects of Plant Protection Products to Non-Target Arthropods. IOBC/WPRS, Gent, Belgium, pp. 45-56.

Schroeder, H.E., Gollasch, S., Moore, A., Tabe, L.M., Craig, S., Hardie, D., Chrispeels, M.J., Spencer, D., Higgins, T.J.V., 1995. Bean $\alpha$-amylase inhibitor confers resistance to the pea weevil, Bruchus pisorum in genetically engineered peas (Pisum sativum L). Plant Physiol. 107, 1233-1239.

Schuler, T.H., Poppy, G.M., Kerry, B.R., Denholm, I., 1998. Insectresistant transgenic plants. Trends in Biotechnol. 16, 168-175.

Selvapandiyan, A., Reddy, V.S., Kumar, P.A., Tewari, K.K., Bhatnagar, R.K., 1998. Transformation of Nicotiana tabacum with a native CrylIa5 gene confers complete protection against Helicoverpa armigera. Mol. Breed. 4, 473-478.

Shade, R.E., Schroeder, H.E., Pueyo, J.J., Tabe, L.M., Murdock, L.L., Higgins, T.J.V., Chrispeels, M.J., 1994. Transgenic pea seeds expressing the $\alpha$-amylase inhibitor of the common bean are resistant to bruchid beetles. Bio/Technol. 12, 793-796.

Shanower, T.G., Kelley, T.G., Cowgill, S.E., 1998. Development of effective and environmentally sound strategies to control Helicoverpa armigera in pigeonpea and chickpea production systems. In: Saini, R.K. (Ed.), Tropical Entomology: Proceedings of the third International Conference on Tropical Entomology. ICIPE Science Press, Nairobi, Kenya, pp. 239-260.

Sharma, K.K., Ortiz, R., 2000. Program for the application of genetic transformation for crop improvement in the semi-arid tropics. In vitro Cell. Dev. Biol.- Plant 36, 83-92.

Sharma, R.P., Yadav, R.P., Singh, R., 1991. Relative efficacy of some insecticides against the field population of bean aphid (Aphis craccivora Koch.) and safety to the associated aphidophagous coccinellid complex occurring on Lathyrus, lentil and chickpea crops. J. Entomol. Res. 15, 251-259.

Sharma, H.C., Sharma, K.K., Seetharama, N., Ortiz, R., 2001. Genetic transformation of crop plants: risks and opportunities for the rural poor. Curr. Sci. 80, 1495-1508.

Sharma, H.C., Crouch, J.H., Sharma, K.K., Seetharama, N., Hash, C.T., 2002. Applications of biotechnology for crop improvement: prospects and constraints. Plant Sci. 163, 381-395.

Sharma, M., Charak, K.S., Ramanaiah, T.V., 2003a. Agricultural biotechnology research in India: status and policies. Curr. Sci. 84, 297-302.

Sharma, H.C., Gowda, C.L.L., Sharma, K.K., Gaur, P.M., Mallikarjuna, N., Buhariwalla, H.K., Crouch, J.H., 2003b. Host plant resistance to pod borer, Helicoverpa armigera in chickpea. In: Chickpea Research for the Millenium. Proceedings, International Chickpea Conference, 20-22 January 2003, Raipur, Chhattisgarh. Indira Gandhi Agricultural University, India, pp. 118-137.

Shi, Y., Wang, M.B., Powell, K.S., van Damme, E., Hilder, V.A., Gatehouse, A.M.R., Boulter, D., Gatehouse, J.A., 1994. Use of the rice sucrose synthase-1 promotor to direct phloem-specific expression of â-glucuronidase and snowdrop lectin genes in transgenic tobacco plants. J. Exp. Bot. 45, 623-631.

Shri, P.V., Davis, T.M., 1992. Zeatin induced shoot regeneration from immature chickpea (Cicer arietinum L.) cotyledons. Plant Cell Tiss. Org. Cult. 28, 45-51.

Silva, C.P., Xavier-Filho, J., 1991. Comparison between the levels of aspartic and cysteine proteinases of the larval midguts of
Callosobruchus maculatus (F.) and Zabrotes subfasciatus (Boh.) (Coleoptera: Bruchidae). Comp. Biochem. Physiol. 99B, 529-533.

Singh, R.P., 1987. Chickpea breeding. In: Saxena, M.C., Singh, K.B. (Eds.), The Chickpea. CAB International, Wallingford, UK, pp. 127-162.

Singh, R., Agarwala, B.K., 1992. Biology, ecology and control efficiency of the aphid parasitoid Trioxys indicus: a review and bibliography. Biol. Agric. Hortic. 8, 271-298.

Singh, J., Sandhu, S.S., Singla, M.L., 1990. Ecology of Heliothis armigera (Hub.) on chickpea in Punjab. J. Insect Sci. 3, 47-52.

Sonia, Rizvi, S.M.H., Singh, R.P., Sharma, K.K., Jaiwal, P.K., 2004. In vitro regeneration and genetic transformation of chickpea. In: Jaiwal, P.K., Singh, R.P. (Eds.), Applied Genetics of Leguminosae Biotechnology; Focus on Biotechnology, Volume 10B. Kluwer Academic Publishers, Dordrecht, The Netherlands, 69-87.

Srinivasu, C.S., Naik, L.K., 2002. Survey for adoptable indigenous methods for the control of stored grain pests. Karnataka J. Agric. Sci. 15, 715-716.

Srivastava, C.P., Srivastava, R.P., 1990. Estimation of avoidable yield loss in chickpea (Cicer arietinum) due to gram-pod borer (Heliothis armigera) in Rajasthan. Indian J. Agric. Sci. 60, 494-496.

Starỳ, P., 1975. Aphidius colemani viereck: its taxonomy, distribution and host range (Hymenoptera, Aphidiidae). Acta Entomol. Bohemoslov. 72, 156-163.

Stoger, E., Williams, S., Christou, P., Down, R.E., Gatehouse, J.A., 1999. Expression of the insecticidal lectin from snowdrop (Galanthus nivalis agglutinin; GNA) in transgenic wheat plants: effects on predation by the grain aphid Sitobion avenae. Mol. Breed. 5, 65-77.

Suhasini, K., Sagare, A.P., Krishnamurthy, K.V., 1994. Direct somatic embryogenesis from mature embryo axis in chickpea (Cicer arietinum L.). Plant Sci. 102, 189-194.

Suzuki, K., Ishimoto, M., Kikuchi, F., Kitamura, K., 1993. Growth inhibitory effect of an $\alpha$-amylase inhibitor from the wild common bean resistant to the Mexican bean weevil (Zabrotes subfasciatus). Japanese J. Breed. 43, 257-265.

Tayyar, R., Federici, C.V., Waines, J.G., 1995. Natural outcrossing in chickpea (Cicer arietinum L.). Crop Sci. 36, 203-205.

Van Emden, H.F., 1999. Transgenic host plant resistance to insectssome reservations. Ann. Entomol. Soc. Am. 92, 788-797.

Van Emden, H.F., Ball, S.L., Rao, M.R., 1988. Pest, disease and weed problems in pea, lentil, faba bean and chickpea. In: Summerfield, R.J. (Ed.), World Crops: Cool Season Food Legumes. Kluwer Academic Publishers, Dordrecht, pp. 519-534.

Van Huis, A., 1991. Biological control methods of bruchid control in the tropics: a review. Insect Sci. Appl. 12, 87-102.

Van Rheenen, H.A., Gowda, C.L.L., Janssen, M.G., 1990. Natural cross-fertilization in chickpea (Cicer arietinum L.). Indian J. Gen. 50, 329-332.

Verma, R., 1991. Life-history and some aspects of biology of Dinarmus basalis (Hymenoptera, Pteromalidae), a parasite of stored legume bruchids. Acta Entomol. Bohemoslov. 88, 359-366.

Waage, J., 1996. Integrated pest management and biotechnology: an analysis of their potential for integration. In: Persley, G.J. (Ed.), Biotechnology and Integrated Pest Management. CAB International, Wallingford, UK, pp. 37-60.

Waterhouse, D.F., 1998. Biological Control of Insect Pests: Southeast Asian Prospects. Australian Centre for International Agricultural Research, Canberra, Australia.

Weigand, S., Pimbert, M.P., 1993. Screening and selection criteria for insect resistance in cool-season food legumes. In: Singh, K.B., Saxena, M.C. (Eds.), Breeding for Stress Tolerance in Cool-Season Food Legumes. John Wiley, Chichester, UK, pp. 145-156.

Weigand, S., Tahhan, O., 1990. Chickpea insect pests in the Mediterranean zones and new approaches to their management. In: Chickpea in the Nineties. Proceedings of the Second 
International Workshop on Chickpea Improvement. 4-8 December 1989, ICRISAT, Patancheru, Andhra Pradesh, pp. 169-175.

Wu, Y., Llewellyn, D., Matthews, A., Dennis, E.S., 1997. Adaptation of Helicoverpa armigera (Lepidoptera: Noctuidae) to a proteinase inhibitor expressed in transgenic tobacco. Mol. Breed. 3, 371-380.

Wu, K., Guo, Y., Lv, N., Greenplate, J.T., Deaton, R., 2002. Resistance monitoring of Helicoverpa armigera to Bacillus thuringiensis insecticidal protein in China. J. Econ. Entomol. 95, $826-831$.

Yadav, T.D., Singh, S., 1994. Persistence toxicity and efficacy of four insecticides as jute fabric treatment to protect cereal and legume seeds. Indian J. Entomol. 56, 146-155.

Yamada, T., Hattori, K., Ishimoto, M., 2001. Purification and characterization of two $\alpha$-amylase inhibitors from seeds of tepary beans (Phaseolus acutifolius A. Gray). Phytochemistry 58, 59-66.

Yoshida, M., Cowgill, S.E., Wightman, J.A., 1995. Mechanisms of resistance to Helicoverpa armigera (Lepidoptera: Noctuidae) in chickpea-role of oxalic acid in leaf exudates as an antibiotic factor. J. Econ. Entomol. 88, 1783-1786.
Yunes, A.N., deAndrade, T.M., Sales, P.M., Morais, R.A., Fernandez, V.S., Gomes, V.M., Xavier-Filho, J., 1998. Legume seed vicilins interfere with the development of the cowpea weevil (Callosobruchus maculatus). J. Agric. Food Chem. 76, 111-116.

Zhang, J.-H., Wang, C.-Z., Qin, J.-D., 2000. The interactions between soybean trypsin inhibitor and $\delta$-endotoxin of Bacillus thuringiensis in Helicoverpa armigera larva. J. Inv. Pathol. 75, 259-266.

Zhao, J.-Z., Cao, J., Li, Y., Collins, H.L., Roush, R.T., Earle, E.D., Shelton, A.M., 2003. Transgenic plants expressing two Bacillus thuringiensis toxins delay insect resistance evolution. Nature Biotech. 21, 1493-1497.

Zhu, K., Huesing, J.E., Shade, R.E., Bressan, R.A., Hasegawa, P.M., Murdock, L.L., 1996. An insecticidal $N$-acetylglucosamine-specific lectin gene from Griffonia simplicifolia (Leguminosae). Plant Physiol. 110, 195-202.

Zhu-Salzmann, K., Ahn, J.-E., Salzman, R.A., Koiwa, H., Shade, R.E., Balfe, S., 2003. Fusion of a soybean cysteine protease inhibitor and a legume lectin enhances anti-insect activity synergistically. Agric. Forest Entomol. 5, 317-323. 